\title{
Regulation of $\delta$-Opioid Receptor Trafficking via $\mu$-Opioid Receptor Stimulation: Evidence from $\mu$-Opioid Receptor Knock-Out Mice
}

\author{
Anne Morinville, ${ }^{1,2}$ Catherine M. Cahill, ${ }^{2}$ M. James Esdaile, ${ }^{2}$ Haneen Aibak, ${ }^{2}$ Brian Collier, ${ }^{1}$ Brigitte L. Kieffer, ${ }^{3}$ and \\ Alain Beaudet ${ }^{2}$ \\ ${ }^{1}$ Department of Pharmacology and Therapeutics, McGill University, Montréal, Québec, Canada H3G 1Y6, ${ }^{2}$ Montréal Neurological Institute, McGill \\ University, Montréal, Québec, Canada H3A 2B4, and 'Institute of Genetics and of Molecular and Cellular Biology, National Center of Scientific Research/ \\ National Institute of Health and of Medical Research, University Louis Pasteur, 67404 Illkirch, France
}

We recently demonstrated that prolonged treatment with morphine increases the antinociceptive potency of the $\delta$-opioid receptor $(\delta 0 \mathrm{R})$ agonist deltorphin and promotes cell surface targeting of $\delta 0 \mathrm{Rs}$ in neurons of the dorsal horn of the rat spinal cord (Cahill et al., 2001b). In the present study we examined whether these effects were mediated selectively via $\mu \mathrm{OR}$. Using the same intermittent treatment regimen as for morphine, we found that methadone and etorphine, but not fentanyl, enhanced [D-Ala ${ }^{2}$ ]-deltorphin-mediated antinociception. However, continuous delivery of fentanyl for $48 \mathrm{hr}$ resulted in augmented $\delta 0 \mathrm{R}$-mediated antinociception when compared with saline-infused animals. Time course studies confirmed that a $48 \mathrm{hr}$ treatment with morphine was necessary for the establishment of enhanced $\delta 0 \mathrm{R}$-mediated antinociception. The observed increases in $\delta 0 \mathrm{R}$ agonist potency and $\delta 0 \mathrm{R}$ plasma membrane density were reversed fully $48 \mathrm{hr}$ after discontinuation of morphine injections. Wild-type C57BL/6 mice pretreated with morphine for $48 \mathrm{hr}$ similarly displayed enhanced $\delta 0 R$-mediated antinociception in a tonic pain paradigm. Accordingly, the percentage of plasma membraneassociated $\delta 0 \mathrm{R}$ in the dorsal horn of the spinal cord, as assessed by immunogold electron microscopy, increased from $6.6 \%$ in naive to $12.4 \%$ in morphine-treated mice. In contrast, morphine treatment of $\mu 0 \mathrm{R}$ gene knock-out (KO) mice did not produce any change in $\delta 0 \mathrm{R}$ plasma membrane density. These results demonstrate that selective activation of $\mu \mathrm{OR}$ is critical for morphine-induced targeting of $\delta 0 \mathrm{R}$ to neuronal membranes, but not for basal targeting of this receptor to the cell surface.

Key words: opiate; targeting; analgesia; narcotic; subcellular localization; electron microscopy

\section{Introduction}

Pharmacological (Martin et al., 1976; Lord et al., 1977) and molecular cloning (Evans et al., 1992; Kieffer et al., 1992; Chen et al., 1993; Fukuda et al., 1993; Meng et al., 1993; Thompson et al., 1993; Wang et al., 1993; Yasuda et al., 1993) data have demonstrated the existence of at least three subtypes $(\mu, \delta$, and $\kappa)$ of opioid receptors (ORs). Several lines of anatomical and pharmacological evidence support a role for at least two of these receptors, $\mu \mathrm{OR}$ and $\delta \mathrm{OR}$, in regulating nociceptive processes. Thus in situ hybridization, autoradiographic binding, and immunocytochemical studies have demonstrated the expression of $\delta \mathrm{OR}$ and $\mu \mathrm{OR}$ within dorsal root ganglion cells and their central afferent terminals in the dorsal horn of the spinal cord (Besse et al., 1990, 1991, 1992b; Dado et al., 1993; Ji et al., 1995; Minami et al., 1995; Wang and Wessendorf, 2001) (for review, see Coggeshall and Carlton, 1997). Furthermore, both $\mu \mathrm{OR}$ and $\delta$ OR have been localized to postsynaptic elements throughout the dorsal horn of the rat spinal cord (Zerari et al., 1994; Arvidsson et al., 1995a,b;

Received Dec. 10, 2002; revised April 1, 2003; accepted April 2, 2003.

This work was supported by a grant from the Canadian Institutes of Health Research (CIHR) awarded to A.B. A.M. was funded by fellowships from the Faculty of Medicine and McGill University. C.M.C. was funded by Merck and Company. We extend our gratitude to Mariette Lavallée and Dr. Pierre Villeneuve for technical assistance.

Correspondence should be addressed to Dr. Alain Beaudet, Department of Neurology and Neurosurgery, Montréal Neurological Institute, Room 896, 3801 University Street, Montréal, Québec, Canada H3A 2B4. E-mail: alain.beaudet@mcgill.ca.

Copyright $\odot 2003$ Society for Neuroscience $\quad$ 0270-6474/03/234888-11\$15.00/0
Cheng et al., 1995; Mansour et al., 1995; Minami et al., 1995; Cahill et al., 2001a). Accordingly, both $\mu \mathrm{OR}$ and $\delta \mathrm{OR}$ agonists were found to be involved in mediating antinociceptive responses at the spinal level. Thus injections of $\mu \mathrm{OR}$-selective agonists, such as fentanyl, morphine, codeine, and L-methadone, into the spinal subarachnoid space produced increases in nociceptive thresholds in acute pain tests in rodents (Yaksh and Rudy, 1976, 1977). These effects were abolished in the presence of selective $\mu \mathrm{OR}$ antagonists and no longer could be elicited in $\mu \mathrm{OR}$ knock-out (KO) mice (Matthes et al., 1996). Similarly, intrathecal administration of $\delta \mathrm{OR}$ agonists induced antinociceptive responses in acute pain tests in rodents (Heyman et al., 1987; Mattia et al., 1992; Stewart and Hammond, 1993), and the percentage of mice displaying analgesia after the same treatment was reduced substantially in $\delta \mathrm{OR}$ KO mice when compared with wild-type (WT) animals (Zhu et al., 1999).

Although $\mu \mathrm{OR}$ and $\delta \mathrm{OR}$ can transduce opioid effects independently, evidence for functional interactions between them has been accumulating. Thus antinociceptive synergy between $\mu \mathrm{OR}$ and $\delta \mathrm{OR}$ agonists has been reported in a number of animal models (Heyman et al., 1989a,b; Jiang et al., 1990; Porreca et al., 1990; Abdelhamid et al., 1991; Malmberg and Yaksh, 1992). Pharmacological and autoradiographic studies have demonstrated changes in the binding of $\delta \mathrm{OR}$-selective ligands with exposure to $\mu$-selective ones (Rothman et al., 1986; Abdelhamid and Takemori, 1991; Besse et al., 1992a; Gouardères et al., 1993). Lately, 
direct interactions between $\mu \mathrm{OR}$ and $\delta \mathrm{OR}$ subtypes via heterodimerization have been demonstrated in vitro in transfected cell systems (George et al., 2000; Gomes et al., 2000).

More recently, we showed that chronic treatment with morphine in vivo triggered recruitment of $\delta \mathrm{ORs}$ to neuronal plasma membranes in the dorsal horn of the rat spinal cord and that this effect was correlated with enhanced $\delta \mathrm{OR}$-mediated antinociception (Cahill et al., 2001b). These results suggest that "priming" of cells by prolonged stimulation with morphine can be exploited to increase the potency of $\delta \mathrm{OR}$ agonists, a finding with potentially important clinical implications. However, the mechanisms underlying this morphine-induced increase in the density of cell surface $\delta$ ORs are still unclear. First, it is unknown whether this effect is specific to morphine or also may be induced by other $\mu \mathrm{OR}$-selective agonists with different capacities to induce receptor-mediated internalization. Second, it is unclear how long $\mu \mathrm{OR}$ must be activated to elicit the observed $\delta \mathrm{OR}$ trafficking response and whether this stimulation must be sustained. Finally, the duration of this morphine-induced upregulation of cell surface $\delta \mathrm{OR}$, which is critical for eventual clinical applications, also is unknown.

The aim of the present study was, therefore, to characterize in the rat the drug specificity and time course of $\delta \mathrm{OR}$ membrane recruitment as well as to ascertain its dependency on $\mu \mathrm{OR}$ stimulation in $\mu \mathrm{OR}$ KO mice.

\section{Materials and Methods \\ Studies with rats \\ Animals}

Experiments used adult male Sprague Dawley rats (200-250 gm; Charles River, Québec, Canada) maintained on a 12 hr light/dark cycle (7 A.M. and 7 P.M.) and allowed free access to food and water. Studies were conducted during the light phase of the cycle, between 10 A.M. and 2 P.M. Experiments were approved by the animal care committee at McGill University and complied with the policies and directives of the Canadian Council on Animal Care.

\section{Acute antinociceptive effects of $\mu \mathrm{OR}$ agonists}

To select comparable dosing for pretreatment with various $\mu \mathrm{OR}$ agonists, we first assessed the acute thermal antinociceptive effects of these drugs [morphine sulfate (MS; $1-10 \mathrm{mg} / \mathrm{kg}$, i.p; Abbott Laboratories, Toronto, Ontario, Canada), methadone hydrochloride $(0.3-10 \mathrm{mg} / \mathrm{kg}$, i.p.; Royal Victoria Hospital, Montreal, Québec, Canada), etorphine hydrochloride (0.3-5 $\mu \mathrm{g} / \mathrm{kg}$, i.p.; Wildlife Pharmaceuticals, Fort Collins, CO), and fentanyl citrate (5-100 $\mu \mathrm{g} / \mathrm{kg}$, i.p.; Sabex, Boucherville, Québec, Canada)] by using the tail-flick test. Tail-flick latencies were determined every $10 \mathrm{~min}$ for up to $1 \mathrm{hr}$. Briefly, the tip of the tail was submerged in a water bath maintained at $52^{\circ} \mathrm{C}$. Latency to response was determined by a vigorous flick of the tail, at which point the response time was recorded. Three baseline readings were obtained before drug injection. A cutoff of $10 \mathrm{sec}$ was imposed to minimize tissue damage in the event that the rat did not respond. If the animal reached cutoff, the tail was removed from the water and the animal was assigned the maximum score. The maximum possible effect (MPE) was calculated according to the following formula:

$\% \mathrm{MPE}=100 \times[$ (test latency) $-($ baseline latency $)] /[$ (cutoff $)-$ (baseline latency)].

\section{Comparative effects of various $\mu \mathrm{OR}$ agonists}

Rats were injected subcutaneously every $12 \mathrm{hr}$ with four increasing doses of one of the four $\mu \mathrm{OR}$ agonists (MS, methadone, etorphine, or fentanyl) diluted in $0.9 \%$ saline solution. Starting doses for chronic treatments were chosen on the basis of the antinociceptive dose-response curves described above. MS was injected at doses of 5, 8, 10 and $15 \mathrm{mg} / \mathrm{kg}$; methadone at doses of $1,1.6,2$, and $3 \mathrm{mg} / \mathrm{kg}$; etorphine at doses of $1,1.6$, 2 , and $3 \mu \mathrm{g} / \mathrm{kg}$; and fentanyl at doses of $10,16,20$, and $30 \mu \mathrm{g} / \mathrm{kg}$. The effect of the selective $\delta \mathrm{OR}$ agonist $\left[\mathrm{D}-\mathrm{Ala}^{2}\right]$-deltorphin-II (DLT) (Tocris
Cookson, Ellisville, MO; Sigma, St. Louis, MO) on tail-flick latencies was determined $8-12 \mathrm{hr}$ subsequent to the last $\mu \mathrm{OR}$ agonist injection. To this end the animals were anesthetized with halothane and injected intrathecally (at L5-L6) with $10 \mu \mathrm{g}$ of DLT diluted in $30 \mu \mathrm{l}$ of saline.

\section{Continuous pretreatment with fentanyl citrate}

Because of its reported short half-life and duration of action (for review, see Gutstein and Akil, 2001), fentanyl citrate also was administered chronically via osmotic mini-pumps (Alza Pharmaceuticals, Cupertino, $\mathrm{CA}$ ). Rats were anesthetized with $66 \mathrm{mg} / \mathrm{kg}$ ketamine hydrochloride (Vetrepharm, Belleville, Ontario, Canada) and $5.5 \mathrm{mg} / \mathrm{kg}$ of xylazine hydrochloride (Novopharm, Toronto, Ontario, Canada). Two mini-pumps, each containing $250 \mu \mathrm{l}$ of $50 \mu \mathrm{g} / \mathrm{ml}$ fentanyl citrate, were inserted subcutaneously between the shoulder blades to ensure continuous delivery of $2 \times 1 \mu \mathrm{l} / \mathrm{hr}$ over $48 \mathrm{hr}$. As a control for the surgery, another group of rats was implanted with one osmotic pump filled with $0.9 \%$ saline. At 48 $\mathrm{hr}$ the mini-pumps were removed under brief ketamine/xylazine anesthesia. Animals were allowed to recover for $4 \mathrm{hr}$ before intrathecal DLT injection and nociceptive testing. Baseline nociceptive thresholds, as assessed by the tail-flick assay, were recorded for each rat before the pumps were removed and immediately before intrathecal DLT injection. Because these baseline thresholds were not significantly different, they were pooled for statistical analyses.

\section{Time course studies}

To determine the minimal duration of morphine pretreatment necessary to induce an increase in $\delta \mathrm{OR}$-mediated antinociception, we treated the rats every $12 \mathrm{hr}$ with increasing doses of MS for $24 \mathrm{hr}(5$ and $8 \mathrm{mg} / \mathrm{kg}$, s.c.), $36 \mathrm{hr}(5,8$, and $10 \mathrm{mg} / \mathrm{kg}$, s.c.) and $48 \mathrm{hr}(5,8,10,15 \mathrm{mg} / \mathrm{kg}$, s.c. $)$. Tail-flick latency responses to intrathecal injections of DLT were determined $12 \mathrm{hr}$ subsequent to the last morphine injection for each group. Controls were injected with $0.9 \%$ saline every $12 \mathrm{hr}$ (4 injections) and were tested $12 \mathrm{hr}$ after the last injection. The experimenter assessing tail-flick latencies was blinded to the animal pretreatment regimen.

\section{Evaluation of antinociceptive tolerance to continuous morphine treatment}

To determine whether our MS pretreatment regimen induced tolerance to morphine, we treated the rats, or not, with MS for $48 \mathrm{hr}$ as above and challenged them $12 \mathrm{hr}$ after the last injection with an intraperitoneal injection of morphine at $1,3,5$, and $10 \mathrm{mg} / \mathrm{kg}$; tail-flick latencies were recorded every $10 \mathrm{~min}$ for $50 \mathrm{~min}$.

\section{Duration of $\mu O R$-induced changes in $\delta O R$ function} and localization

$\delta O R$-mediated antinociception. To determine the duration of MSinduced enhancement of $\delta \mathrm{OR}$-mediated antinociception, we treated the rats for $48 \mathrm{hr}$ with MS as above and tested them for $\delta$ OR-mediated antinociception $12,24,36$, or $48 \mathrm{hr}$ subsequent to the last morphine injection. Controls were treated in parallel with $0.9 \%$ saline but were tested only at $12 \mathrm{hr}$ after the last injection. Here again, the experimenter assessing tail-flick latencies was blinded to the rat pretreatment regimen.

Subcellular localization of $\delta O R$. To determine $\delta$ OR plasma membrane density after chronic morphine treatment, we pretreated the rats for $48 \mathrm{hr}$ with MS as above and assessed the subcellular localization of $\delta$ OR by electron microscopic immunocytochemistry $48 \mathrm{hr}$ after the last morphine injection $(n=3)$. Results then were compared with those observed in similarly treated animals $12 \mathrm{hr}$ after the last morphine injection (Cahill et al., 2001b). $\delta$ OR immunolabeling was performed as previously described (Cheng et al., 1995; Cahill et al., 2001a,b). Briefly, rats were anesthetized with sodium pentobarbital and perfusion-fixed with $50 \mathrm{ml}$ of $3.75 \%$ acrolein $/ 2 \%$ paraformaldehyde (PFA) in $0.1 \mathrm{M}$ phosphate buffer (PB), pH 7.4, followed by $400 \mathrm{ml}$ of $2 \%$ PFA in $0.1 \mathrm{M} \mathrm{PB}, \mathrm{pH}$ 7.4. Lumbar spinal cords were postfixed in $2 \%$ PFA in $0.1 \mathrm{M} \mathrm{PB}$ for 30 min and serially sectioned $(40-50 \mu \mathrm{m})$ on a vibrating microtome. Sections were incubated for $30 \mathrm{~min}$ with $1 \%$ sodium borohydride in $0.1 \mathrm{M} \mathrm{PB}$ and then for a further $30 \mathrm{~min}$ in $25 \%$ sucrose/3\% glycerol in $0.1 \mathrm{M}$ PB before snapfreezing with isopentane $\left(-70^{\circ} \mathrm{C}\right)$, liquid nitrogen, and finally thawing in $0.1 \mathrm{~m}$ PB. Sections were rinsed with $0.1 \mathrm{~m}$ TBS, blocked with $3 \%$ NGS, and immunolabeled for $36-48 \mathrm{hr}$ at $4^{\circ} \mathrm{C}$ with a $\delta \mathrm{OR}$ antiserum (catalog 
A
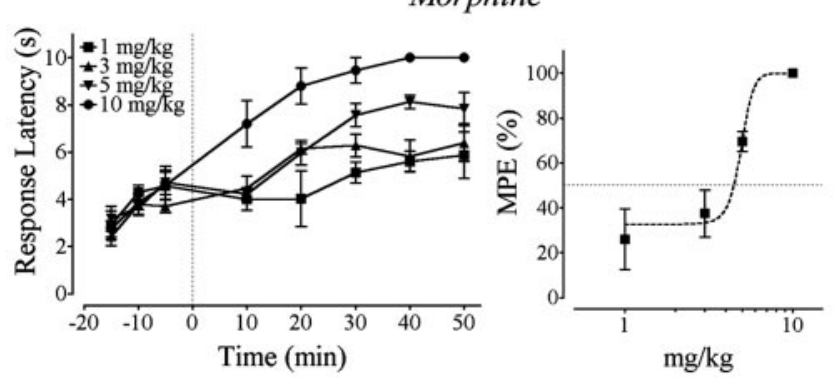

$\mathrm{C}$

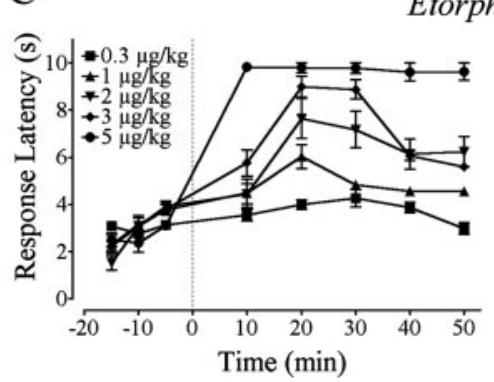

Etorphine

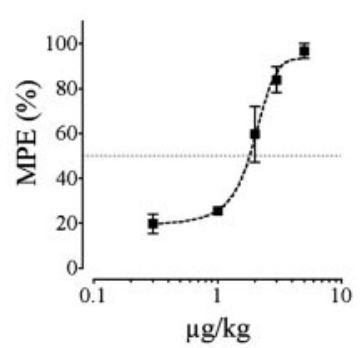

B

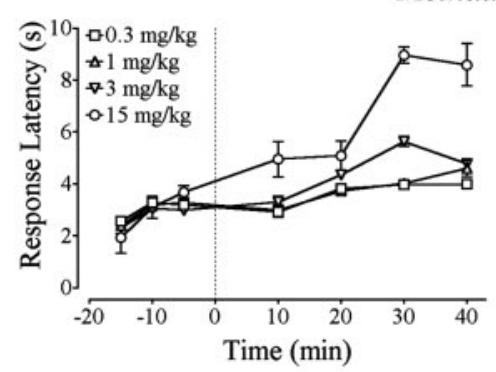

Methadone

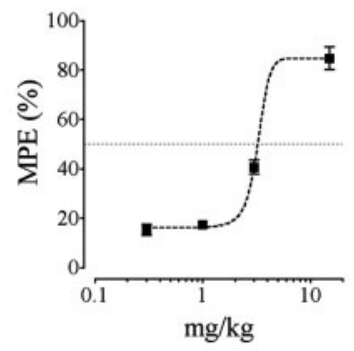

$\mathrm{D}$

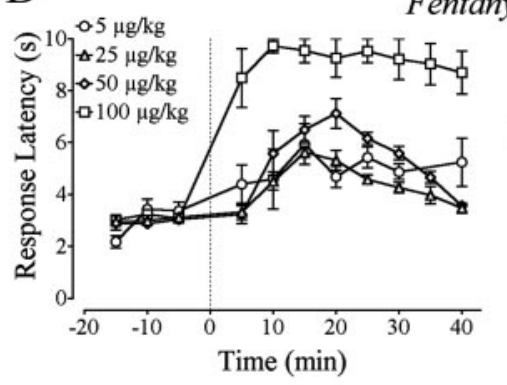

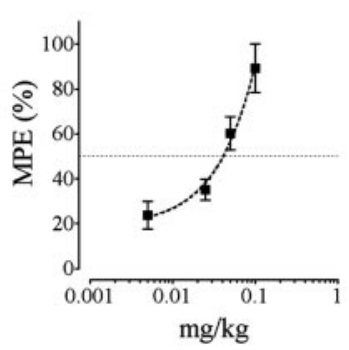

Figure 1. Comparative antinociceptive potencies of four $\mu O R$ agonists in an acute pain paradigm. Left panels, Tail-flick latencies (in sec) were determined every 10 min subsequent to intraperitoneal administration (time 0 , denoted by dotted line) of morphine $(A)$, methadone $(B)$, etorphine $(C)$, and fentanyl $(D)$ at various doses. Right panels, The percentage of the maximum possible effect (\% MPE) was calculated at the time of peak antinociceptive response for each dose: $40 \mathrm{~min}$ for morphine $(A), 30 \mathrm{~min}$ for methadone (B), $30 \mathrm{~min}$ for etorphine ( $C$, and $20 \mathrm{~min}$ for fentanyI $(D)$. The theoretical equation of the line (sigmoidal dose-response) is shown as a dotted curve (right panel). $\mathrm{ED}_{50}$ values were estimated from the theoretical curve at an MPE of $50 \%$ (dotted horizontal line, right panel). Calculations were performed with Excel 97 (Microsoft) and Prism 3.02 (Graph Pad Software). Data are presented as the average \pm SEM.

number AB1560,Chemicon, Temecula, CA) diluted to $0.2-0.5 \mu \mathrm{g} / \mathrm{ml}$ in TBS containing $0.5 \%$ NGS. As controls the sections were processed in the absence of primary antibody. Sections then were incubated at room temperature for $2 \mathrm{hr}$ with a 1:50 dilution of colloidal gold-conjugated $(1 \mathrm{~nm})$ goat anti-rabbit IgG (AuroProbe One GAR, Amersham Biosciences, Baie D’Urfé, Québec, Canada) diluted in 0.1 м PBS, pH 7.4, containing 2\% gelatin and $8 \%$ BSA. After thorough washing the sections were fixed with $2 \%$ glutaraldehyde, and immunogold deposits were enhanced by incubation with ionic silver (IntenSE M Silver Enhancement Kit, Amersham Biosciences). Sections were postfixed with $2 \% \mathrm{OsO}_{4}$, dehydrated in graded alcohols, embedded in Epon, thin-sectioned $(80 \mathrm{~nm})$, counterstained with uranyl acetate and lead citrate, and observed with a JEOL 100CX transmission electron microscope (JEOL, Peabody, MA).

For quantification of the distribution of immunolabeled $\delta \mathrm{OR}$, a minimum of 50 immunopositive dendrites from the dorsal horn (lamina III-IV) of the spinal cord was counted in each animal. Dendrites of similar size were sampled in all treatment groups. Profiles were considered to be immunolabeled if two or more gold particles were present over them. Gold particles were classified as being intracellular or plasma membrane-associated as described (Cahill et al., 2001a,b). The percentage of membrane-associated to total gold particles for each animal was calculated by dividing the sum of the number of gold particles found at the cell surface by the sum of immunogold particles detected for all sampled dendrites.

\section{Studies with mice}

Animals

Behavioral experiments used both male and female WT C57BL/6 mice (8-15 weeks of age; Charles River, Québec, Canada). Subcellular localization studies were performed on homozygous female and male mice $\mu \mathrm{OR} \mathrm{KO}$ as well as on male and female WT C57BL/6 mice. The generation of $\mu \mathrm{OR}$ KO C57BL/6 mice has been described in detail previously (Matthes et al., 1996). Animals were maintained on a $12 \mathrm{hr}$ light/dark cycle, and experiments were performed during the light phase of the cycle, between 10 A.M. and 2 P.M. Experiments were approved by the
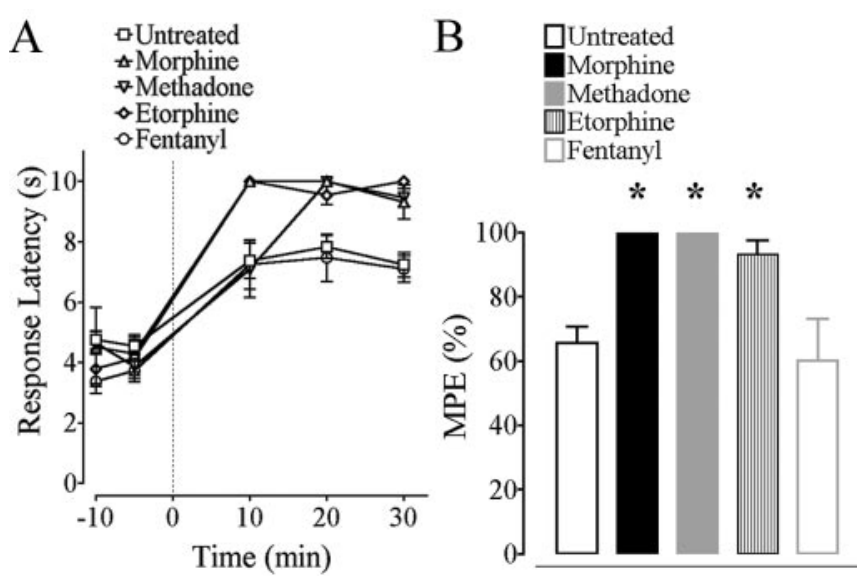

Figure 2. Effect of chronic pretreatment with $\mu O R$ agonists on $\delta 0 \mathrm{R}$-mediated antinociception. $A$, Morphine, methadone, etorphine, and fentanyl were administered at $12 \mathrm{hr}$ intervals for $36 \mathrm{hr}$ as described in the Materials and Methods. Then $12 \mathrm{hr}$ subsequent to the last injection of each opioid ligand, $10 \mu \mathrm{g}$ of DLT was administered intrathecally, and tail-flick latencies (in sec) were recorded every $10 \mathrm{~min} . B$, Each bar in the graph represents the percentage of maximal possible effect (MPE) \pm SEM 20 min after the injection of DLT. The percentages of MPE for morphine $(n=4 ; p<0.01)$, methadone $(n=6 ; p<0.01)$, and etorphine $(n=6, p<0.05)$ were significantly different from the \% MPE of non-pretreated rats ( $n=13$; ANOVA, Tukey's MCT; denoted by an asterisk). No significant difference was found between the \% MPE for fentanyl-pretreated $(n=5)$ and non-pretreated rats ( $p>0.05$; ANOVA, Tukey's MCT) or among the percentages of MPE for morphine, methadone, and etorphine ( $p>0.05$; ANOVA, Tukey's MCT).

animal care committee at McGill University and complied with the policies and directives of the Canadian Council on Animal Care.

\section{Behavioral studies with mice}

To determine whether chronic morphine treatment induced enhanced $\delta$ OR-mediated antinociception in mice as it does in the rat, we pre- 
A

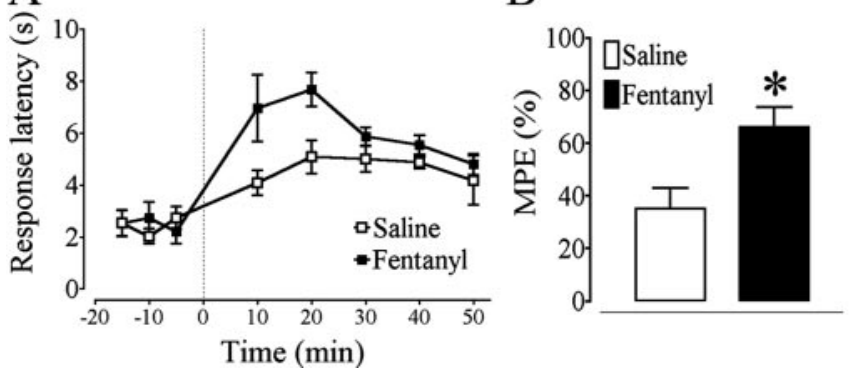

Figure 3. Continuous administration of fentanyl leads to enhanced DLT-mediated antinociception. A, Rats were implanted subcutaneously with osmotic mini-pumps for continuous delivery of $0.1 \mu \mathrm{g} / \mathrm{hr}$ fentanyl over $48 \mathrm{hr}$; saline controls were implanted osmotic pumps delivering $1 \mu \mathrm{l}$ of $0.9 \%$ saline/hr for $48 \mathrm{hr}$. Pumps were removed $4 \mathrm{hr}$ before antinociceptive testing. Baseline latencies were measured before and after the removal of the pumps and every $10 \mathrm{~min}$ subsequent to the intrathecal administration of DLT. $B$, Each bar in the graph represents the \% MPE \pm SEM calculated 20 min after the injection of DLT ( $n=5$ for each group). Statistical significance was determined by the means of an unpaired Student's $t$ test $\left({ }^{*} p<0.05\right)$.

treated, or not, both male and female wild-type C57BL/6 mice with morphine sulfate at 5, 8, 10,15 mg/kg (subcutaneously every $12 \mathrm{hr}$ ) and tested them for $\delta$ OR-mediated antinociception $8-12 \mathrm{hr}$ subsequent to the last morphine injection. For this purpose the mice were anesthetized lightly with isoflurane and administered intrathecally with $5 \mu \mathrm{l}$ of saline or $5 \mu \mathrm{g}$ of DLT in $5 \mu \mathrm{l}$ of saline at the L4-L5 intervertebral space. Mice then were tested for $\delta$ OR-mediated antinociception by the formalin test $(n=4-6$ female and 4-7 male mice in each group). This test was used because mice of this particular strain respond better to this tonic pain stimulus than to the acute tail-flick test (Mogil et al., 1999) and because both tests are equally sensitive for detecting morphine-induced enhancement of SOR-mediated antinociception in the rat (Cahill et al., 2001b). In C57BL/6 mice an intraplantar injection $(25 \mu \mathrm{l})$ of formalin $(2.5 \%)$ produced the biphasic nociceptive response typical of this persistent pain model. Nocifensive behaviors were assessed by a weighed score as previously described (Coderre et al., 1993). Briefly, the nocifensive behavior was assessed as 1, no favoring of the injected hind paw; 2, favoring; 3 , complete elevation of the hind paw from the floor; 4 , licking or flinching. The behavior was evaluated in $5 \mathrm{~min}$ intervals, and the severity of the response was determined by the following formula: $[(0 \times$ the time spent in category $\# 1+1 \times$ the time spent in category $\# 2+2 \times$ the time spent in category $\# 3+3 \times$ the time spent in category $\# 4) / 300]$.

The total area under the curve (A.U.C.) (phases 1 and 2) was calculated for each animal.

\section{Subcellular localization of $\delta O R$}

Wild-type and $\mu$ OR KO mice were pretreated or not with MS for $48 \mathrm{hr}$ as above and perfusion-fixed $12 \mathrm{hr}$ after the last morphine injection, under pentobarbital anesthesia ( $2.9 \mathrm{mg} / \mathrm{mouse})$, with $35 \mathrm{ml}$ of a mixture of $3.75 \%$ acrolein and $2 \%$ PFA, followed by $250 \mathrm{ml}$ of $2 \%$ PFA in $0.1 \mathrm{M} \mathrm{PB}$, $\mathrm{pH}$ 7.4. Lumbar spinal cords were postfixed with $2 \%$ PFA in $0.1 \mathrm{M} \mathrm{PB}$ for $30 \mathrm{~min}$, sectioned on a vibratome, and processed for $\delta \mathrm{OR}$ immunogold labeling as described above. Specificity controls were obtained by replicating the experimental conditions in the absence of primary antibody.

For quantification of the distribution of immunolabeled $\delta \mathrm{OR}$ a minimum of 50 immunopositive dendrites from the dorsal horn (lamina II-V) of each mouse was counted in untreated ( $n=3 ; 2$ male, 1 female) and morphine-pretreated ( $n=3 ; 3$ female) WT mice as well as in untreated $(n=3 ; 3$ female) and morphine-treated ( $n=3 ; 2$ female, 1 male) $\mu \mathrm{OR}$ KO mice. Profiles were considered to be immunolabeled if three or more gold particles were present over them. For each animal the density of immunoreactive $\delta$ OR per unit length of membrane was calculated by dividing the total number of gold particles detected at the surface of all sampled dendrites by the sum of the respective perimeters (measured by computer-assisted morphometry; Biocom, Les Ulis, France). Similarly, for each animal the number of $\delta \mathrm{OR}$ per unit area $\left(\mu \mathrm{m}^{2}\right)$ was calculated by dividing the sum of the total number of gold particles detected over dendritic profiles by the sum of their surface areas. Finally, the percentage of membrane-associated to total gold particles for each animal was calculated as in the rat material.

\section{Results}

\section{Studies with rats}

Comparative analgesic potencies of $\mu \mathrm{OR}$ agonists

To select equi-effective doses of opioids for chronic pretreatments, we compared the acute antinociceptive effects of the $\mu \mathrm{OR}$ agonists morphine, methadone, etorphine, and fentanyl in an acute pain paradigm (Fig. 1). Intraperitoneal administration of morphine, methadone, and etorphine produced peak antinociceptive responses in the tail-flick test 30-40 min subsequent to injection of the $\mu \mathrm{OR}$ agonist (Fig. $1 A-C$, respectively). For fentanyl, peak antinociceptive responses were recorded 10-20 min after injection (Fig. $1 D$ ), consistent with the reported pharmacokinetic profile of this drug (for review, see Gutstein and Akil, 2001). To generate a dose-response curve, we calculated the percentage of the maximum possible effect (\% MPE) at the time of peak antinociceptive response for each $\mu \mathrm{OR}$ agonist at each dose. $\mathrm{ED}_{50}$ values, estimated from the MPE of $50 \%$, were $5 \mathrm{mg} / \mathrm{kg}$ for morphine (Fig. $1 A$ ), $3 \mathrm{mg} / \mathrm{kg}$ for methadone (Fig. $1 B$ ), and 1.5 $\mu \mathrm{g} / \mathrm{kg}$ for etorphine (Fig. $1 C$ ). For fentanyl the best estimate of the $\mathrm{ED}_{50}$ was $40 \mu \mathrm{g} / \mathrm{kg}$ (Fig. $1 D$ ).

\section{Effect of chronic $\mu O R$ agonist administration on \\ $\delta O R$-mediated antinociception}

Then a separate group of animals was treated chronically on an intermittent dosage regimen with morphine, methadone, etorphine, or fentanyl (Fig. 2). The starting dose of each drug was based on its respective $\mathrm{ED}_{50}$ to use a dose equivalent to that used
A

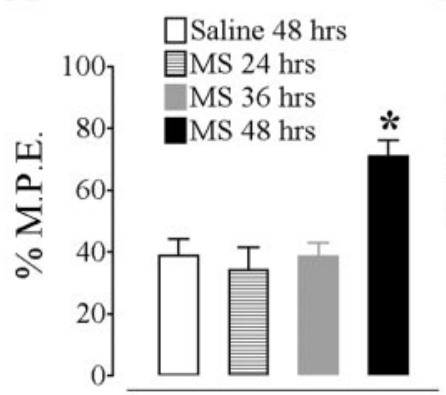

B

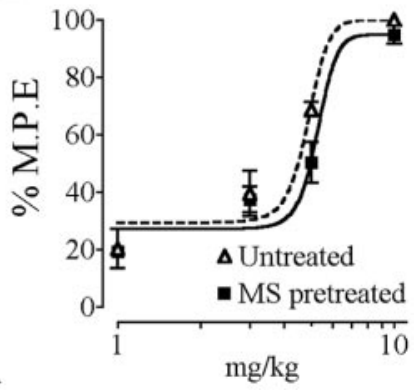

Figure 4. A, Time course for the establishment of enhanced $\delta 0 \mathrm{R}$-mediated antinociception. Rats were treated with morphine sulfate (MS) at 5 and $8 \mathrm{mg} / \mathrm{kg}$ (subcutaneously at $12 \mathrm{hr}$ intervals); 5,8 , and $10 \mathrm{mg} / \mathrm{kg}$ (subcutaneously at $12 \mathrm{hr}$ intervals); or $5,8,10,15 \mathrm{mg} / \mathrm{kg}$ (subcutaneously at $12 \mathrm{hr}$ intervals). Tail-flick latency responses to intrathecal injections of DLT were determined $12 \mathrm{hr}$ subsequent to the last morphine injection. The data were expressed as a function of the time that had elapsed between the first morphine injection and the time of testing (i.e., MS 24, 36, and $48 \mathrm{hr}$ ). Saline controls were injected subcutaneously with $0.9 \%$ saline every $12 \mathrm{hr}$ ( 4 injections) and were tested $12 \mathrm{hr}$ after the last injection (Saline $48 \mathrm{hr}$ ). Each bar represents the \% MPE \pm SEM 20 min after the injection of DLT. Morphine treatment for 48 hr ( $p<0.001)$, but not treatment for 24 or $36 \mathrm{hr}$ ( $p>0.05$ in both cases), produced DLTmediated antinociception that was significantly greater than that observed in saline-injected animals (denoted by an asterisk). Statistical significance was determined by ANOVA, followed by Dunnett's MCT. $B$, Evaluation of antinociceptive tolerance to continuous morphine treatment. Rats were pretreated or not with morphine (MS) at 5, 8, 10, and $15 \mathrm{mg} / \mathrm{kg}$ (subcutaneously every $12 \mathrm{hr}$ ). At $12 \mathrm{hr}$ after the last morphine administration the rats were injected intraperitoneally with morphine at 1, 3, 5, or $10 \mathrm{mg} / \mathrm{kg}$; tail-flick latency responses were determined every $10 \mathrm{~min}$ for $50 \mathrm{~min}$. Each data point represents the \% MPE \pm SEM $30 \mathrm{~min}$ after the morphine challenge ( $n=4-6$ for each point). No statistical difference at any of the doses was observed between untreated (dotted) and morphine-pretreated (solid line) rats (unpaired $t$ tests, $p>0.05$ ). Calculations were performed with Excel 97 (Microsoft) and Prism 3.02 (Graph Pad Software). 


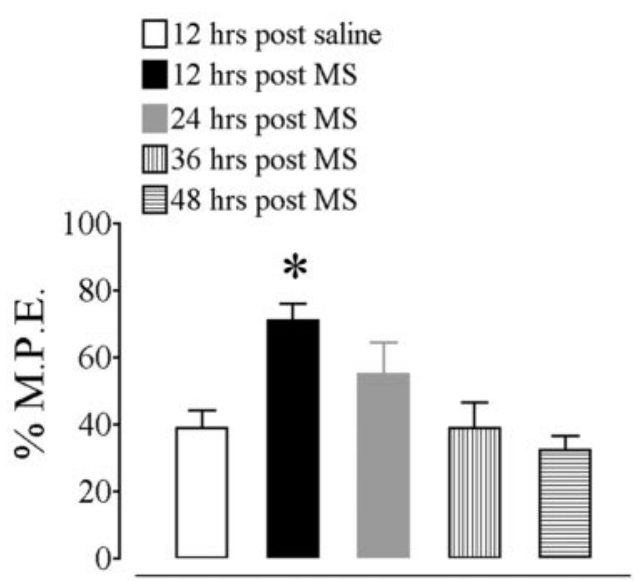

Figure 5. Duration of enhanced DLT-mediated antinociception. Rats were injected with 5, 8, $10,15 \mathrm{mg} / \mathrm{kg}$ morphine (MS; subcutaneously at $12 \mathrm{hr}$ intervals). DLT-mediated antinociception was determined $12 \mathrm{hr}(n=11), 24 \mathrm{hr}(n=6), 36 \mathrm{hr}(n=5)$, and $48 \mathrm{hr}(n=5)$ subsequent to the last morphine injection. The data were expressed as a function of the time that had elapsed between the last morphine injection and the time of testing (i.e., 12, 24, and $48 \mathrm{hr}$ after MS). Saline controls were injected subcutaneously with $0.9 \%$ saline every $12 \mathrm{hr}$ ( 4 injections) and were tested for DLT-mediated antinociception $12 \mathrm{hr}$ after the last saline injection. Each bar represents the \% MPE \pm SEM 20 min after the injection of DLT. The asterisk denotes a statistically significant increase when compared with saline-treated controls $(p<0.001$; ANOVA, Dunnett's MCT).

for the morphine pretreatment (Fig. 2). The antinociceptive effects of the selective $\delta$ OR agonist DLT were tested $12 \mathrm{hr}$ after the last injection of the $\mu \mathrm{OR}$ agonist ( $48 \mathrm{hr}$ after the first injection). Intrathecal administration of DLT in untreated and $\mu \mathrm{OR}$ agonist-pretreated rats elicited antinociception in the tail-flick test, as exhibited by the increase in latency to response when compared with baseline values in this acute pain model (Fig. $2 A$ ). However, rats pretreated with morphine $(p<0.01)$, methadone $(p<0.01)$, or etorphine $(p<0.05)$ showed significantly higher DLT-induced antinociception than that produced in untreated animals (Fig. 2B; ANOVA, Tukey's test). When we compared \% MPEs 20 min after intrathecal injection of DLT, no significant difference was found among morphine, etorphine, and methadone-pretreated rats (Fig. 2 B; ANOVA, Tukey's test; $p>$ $0.05)$. In contrast, rats pretreated with the highly selective $\mu \mathrm{OR}$ agonist fentanyl showed the same level of DLT-induced antinociception as untreated rats (Fig. $2 B$; ANOVA, Tukey's test; $p>$ $0.05)$.

To test the possibility that the lack of effect of fentanyl may be attributable to the in vivo pharmacokinetic profile of the drug (rapid onset of action and short half-life), we treated animals at shorter time intervals (every 8 or $6 \mathrm{hr}$ for $40 \mathrm{hr}$ ) with increasing doses of fentanyl. This treatment strategy also failed to produce an enhancement in DLT-induced antinociception in the tail-flick test 48-50 hr after the start of fentanyl treatments (results not shown). To ensure continuous exposure to fentanyl, we implanted two osmotic pumps subcutaneously for delivery of 0.1 $\mu \mathrm{g} / \mathrm{hr}$ for $48 \mathrm{hr}$. Continuous delivery of fentanyl in this manner resulted in a significant increase in DLT-mediated antinociception (Fig. 3; $p<0.05$ ) as compared with saline-infused controls.

Time course studies

To determine the time needed for the establishment of enhanced $\delta \mathrm{OR}-$ mediated antinociception via chronic $\mu \mathrm{OR}$ agonist treatment, we treated the rats with morphine for different time intervals: $24 \mathrm{hr}$ ( 5 and $8 \mathrm{mg} / \mathrm{kg}$, s.c., every $12 \mathrm{hr}), 36 \mathrm{hr}(5,8,10 \mathrm{mg} / \mathrm{kg}$, s.c., every $12 \mathrm{hr})$, or $48 \mathrm{hr}(5,8,10$, and $15 \mathrm{mg} / \mathrm{kg}$, s.c. every $12 \mathrm{hr})$.
In all cases intrathecal injections of DLT were performed 8-12 hr after the last morphine injection. The \% MPE 20 min after DLT was significantly greater after the $48 \mathrm{hr}$ pretreatment when compared with saline-pretreated animals [Fig. 4A; ANOVA, Dunnett's multiple comparison test (MCT); $p<0.001$ ]. In contrast, the $\%$ MPE for pretreatment with morphine for 24 or $36 \mathrm{hr}$ was not significantly different from that of saline-injected rats (Fig. $4 A$; ANOVA, Dunnett's MCT; $p>0.05)$.

\section{Evaluation of antinociceptive tolerance to continuous morphine treatment}

To determine whether our treatment paradigm induced tolerance to morphine, we pretreated, or not, the rats with morphine at $5,8,10$, and $15 \mathrm{mg} / \mathrm{kg}$ (subcutaneously every $12 \mathrm{hr}$ ), and we tested their nociceptive response after a single intraperitoneal injection of morphine $12 \mathrm{hr}$ after the last dose of the pretreatment. As can be seen in Figure $4 B$, no statistically significant difference was detected in the antinociceptive effects of an acute morphine challenge at any of the doses tested between morphine-pretreated versus untreated rats (unpaired Student's $t$ tests; $p>0.05$ ).

Duration of enhanced $\delta O R$ function and cell surface upregulation To determine the duration of the morphine-induced increase in SOR-mediated antinociception, we pretreated the rats with 5, 8 , $10,15 \mathrm{mg} / \mathrm{kg}$ morphine (subcutaneously every $12 \mathrm{hr}$ ) and subsequently tested them for $\delta$ OR-mediated antinociception 12,24 , 36 , and $48 \mathrm{hr}$ after the last morphine injection (Fig. 5). A statistically significant enhancement of $\delta \mathrm{OR}$-mediated antinociception was observed $12 \mathrm{hr}$ subsequent to the last morphine injection as compared with saline-pretreated rats (Fig. 5; $p<0.001$ ). At 24 $\mathrm{hr}$ after the last morphine injection the \% MPE for intrathecal DLT appeared elevated, albeit not significantly different from controls (Fig. 5). After 36 and 48 hr DLT-mediated antinociception had returned to the levels measured in saline-pretreated rats (Fig. 5).

Our previous studies had shown that the increase in $\delta \mathrm{OR}$ agonist potency observed $12 \mathrm{hr}$ after the last injection of morphine was correlated with an upregulation of $\delta \mathrm{ORs}$ at the cell

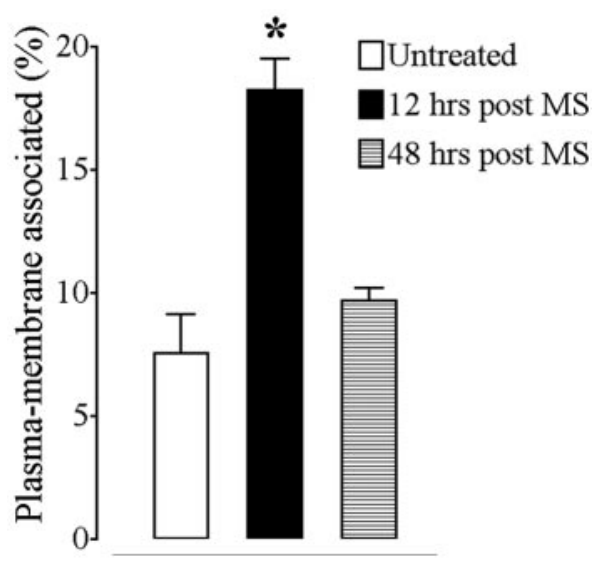

Figure 6. Subcellular distribution of $\delta 0 \mathrm{R} 48 \mathrm{hr}$ after the last dose of the morphine pretreatment regimen. Rats ( $n=3$ ) were injected with 5, 8, 10, $15 \mathrm{mg} / \mathrm{kg}$ morphine (MS; subcutaneously at $12 \mathrm{hr}$ intervals) and were processed for immunogold detection of $\delta 0 \mathrm{Rs} 12 \mathrm{and} 48 \mathrm{hr}$ subsequent to the last morphine injection ( 12 and $48 \mathrm{hr}$ post-MS, respectively). Untreated rats were processed for electron microscopic detection of $\delta 0 \mathrm{Rs}$ in an analogous manner. Each bar represents the proportion of immunogold particles associated with the plasma membrane as a percentage of the total \pm SEM. This percentage is not significantly different between $48 \mathrm{hr}$ post-MS and untreated rats (ANOVA, Tukey's MCT; $p>0.05$ ) but is significantly greater at $12 \mathrm{hr}$ post-MS rats when compared with either $48 \mathrm{hr}$ post-MS or untreated rats (ANOVA, Tukey's MCT; $p<0.01$; denoted by an asterisk). 

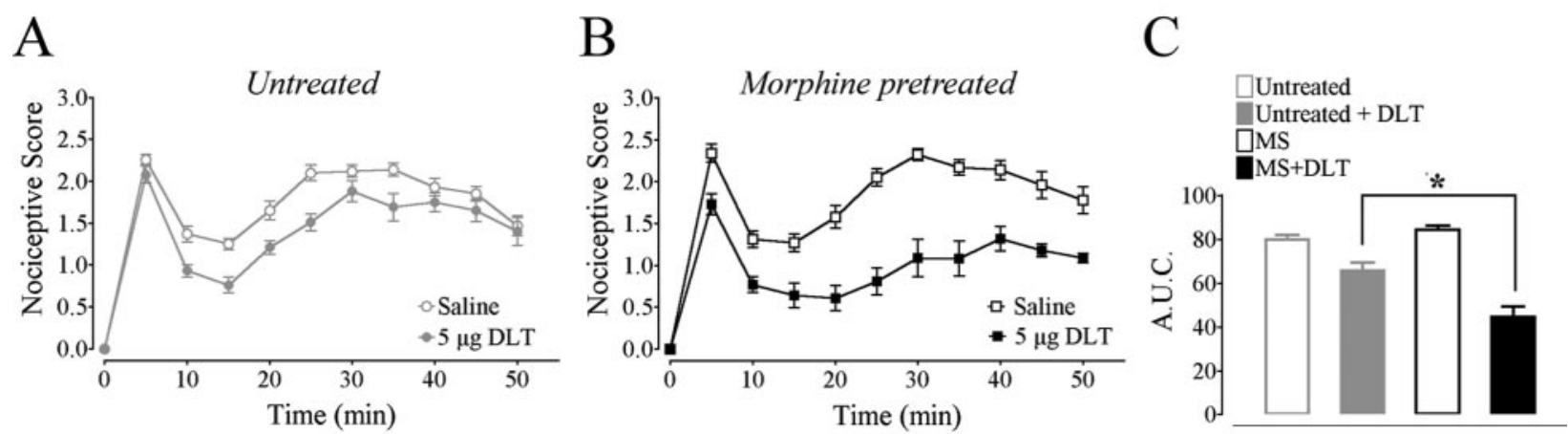

Figure 7. Prolonged treatment with morphine leads to enhanced $\delta 0 R$-mediated antinociception in $C 57 \mathrm{BL} / 6$ mice. WT male and female mice were pretreated $(B)$ or not $(A)$ with morphine sulfate at $5,8,10,15 \mathrm{mg} / \mathrm{kg}$ (subcutaneously every $12 \mathrm{hr}$ ). At $12 \mathrm{hr}$ after the last morphine injection, saline or $5 \mu \mathrm{g}$ of DLT was injected intrathecally. In C57BL/6 mice an intraplantar injection of formalin (2.5\%) produced the biphasic nociceptive response typical of this persistent pain model $(A, B)$. Nocifensive behaviors in female $(n=4-6$ per group) and male $(n=4-7$ per group) mice were assessed in 5 min intervals with a weighted score. Because nocifensive scores were not statistically different between males and females (see Table 1), pooled male and female scores are illustrated. C, Pooled area under the curve (A.U.C.) for male and female mice. The A.U.C. values for intrathecal saline in morphine and untreated animals are not significantly different. However, there is a statistically significant decrease in A.U.C. between saline-treated mice and morphine-pretreated mice intrathecally injected with DLT (ANOVA, Bonferroni MCT; $p<0.001 ;$ denoted by an asterisk). Data are presented as the average \pm SEM.

surface (Cahill et al., 2001b). To determine whether, conversely, the return of $\delta \mathrm{OR}$ antinociceptive responses to baseline levels was accompanied by a restoration of $\delta \mathrm{OR}$ membrane density to basal levels, we pretreated the rats with $5,8,10,15 \mathrm{mg} / \mathrm{kg}$ morphine and assessed the subcellular localization of $\delta \mathrm{OR} 48 \mathrm{hr}$ after the last morphine injection in dendrites from lamina III-IV of the dorsal horn of the spinal cord. As we previously reported, $12 \mathrm{hr}$ after the last morphine injection a significant increase was observed in the percentage of $\delta \mathrm{OR}$ immunoreactive gold particles found in association with dendritic plasma membranes as compared with controls (Fig. 6; ANOVA, Tukey's MCT; $p<0.01$ ). In contrast, $48 \mathrm{hr}$ after the last morphine injection the percentage of plasma membrane-associated immunogold particles was no longer significantly different from that observed in untreated animals (Fig. 6; ANOVA, Tukey's MCT; $p>0.05$ ). This result demonstrates a return of $\delta \mathrm{OR}$ plasma membrane density to premorphine treatment levels $48 \mathrm{hr}$ after removal of the $\mu \mathrm{OR}$ agonist.

\section{Studies with mice}

Behavioral studies

To determine whether chronic pretreatment with $\mu \mathrm{OR}$ agonists also induced an increase in DLT-induced antinociception in mice, we injected wild-type male and female C57BL/6 mice with increasing doses of morphine $(5,8,10$, and $15 \mathrm{mg} / \mathrm{kg})$ every $12 \mathrm{hr}$. Antinociception produced by intrathecal administration of DLT was assessed in untreated and morphine-treated male and female mice by the formalin test $8-12 \mathrm{hr}$ after the last morphine dose, as previously described for rats (Cahill et al., 2001b). Intrathecal administration of DLT in mice elicited antinociception, as exhibited by the inhibition of formalin-induced nocifensive behaviors in both untreated and morphine-treated mice (Fig. 7A,B; compare intrathecal saline vs $5 \mu \mathrm{g}$ of DLT). For both male and female mice a statistically significant decrease in the A.U.C. was noted between untreated and morphine-pretreated mice injected intrathecally with DLT (Table 1; Fig. 7C). This difference indicates a significant increase in $\delta \mathrm{OR}$-mediated antinociception, and hence of $\delta \mathrm{OR}$ agonist effectiveness, in morphine-treated as compared with untreated mice. Because the effect was similar in male and female mice, subcellular distribution data subsequently were pooled between the two genders.
Table 1. Comparison of the A.U.C. for nocifensive behaviors elicited by intraplantar formalin injection in male and female wild-type C57BL/6 mice

\begin{tabular}{lll}
\hline & & A.U.C. \\
\hline WT C57BL/6 male mice & Untreated & $78.68 \pm 3.139$ \\
& Untreated + DLT & $55.88 \pm 5.060$ \\
& MS-pretreated & $85.75 \pm 3.182$ \\
& MS-pretreated + DLT & $36.50 \pm 5.556^{*}$ \\
WT C57BL/6 female mice & Untreated & $81.58 \pm 3.205$ \\
& Untreated + DLT & $72.16 \pm 2.621$ \\
& MS-pretreated & $82.82 \pm 2.529$ \\
& MS-pretreated + DLT & $52.75 \pm 5.303^{* *}$ \\
\hline
\end{tabular}

DLT, $5 \mu \mathrm{g}$ of Deltorphin.

${ }^{*} p<0.01$ (ANOVA, Bonferroni's MCT, untreated plus DLT vs MS-pretreated plus DLT).

${ }^{* *} p<0.001$ (ANOVA, Bonferroni's MCT, untreated plus DLT vs MS-pretreated plus DLT).

Effect of morphine pretreatment on subcellular distribution of $\delta O R$ in mouse spinal cord

To determine whether in mice, as in rats, pretreatment with morphine increases the cell surface density of $\delta \mathrm{OR}$, we studied the subcellular distribution of immunoreactive $\delta$ OR by electron microscopy. In the dorsal horn (lamina II-V) of untreated wild-type C57BL/6 mice, silver-intensified immunogold particles, corresponding to immunoreactive $\delta \mathrm{OR}$, were detected in association with perikarya and dendrites (Fig. $8 \mathrm{~A}$ ) of small intrinsic neurons as well as with axons and axon terminals. Within these immunolabeled neurons most immunoreactive $\delta \mathrm{ORs}$ were intracellular rather than on the plasma membrane (Fig. $8 A$ ).

Pretreatment of WT mice with morphine $(5,8,10,15 \mathrm{mg} / \mathrm{kg}$, s.c., every $12 \mathrm{hr}$ ) did not produce any significant change in the number of immunogold particles detected per unit area of dorsal horn dendrites when compared with untreated WT mice (Figs. $8 B, 10 A)$. However, the density of immunogold particles per unit length of plasma membrane was increased significantly from 0.09 to 0.18 (Fig. $10 B ; p<0.01$ ). Furthermore, the percentage of gold particles associated with dendritic plasma membranes in the same area was increased significantly from $6.6 \%$ of total gold particles in untreated to $12.4 \%$ of total gold particles in morphine-treated WT mice (Fig. 10C; $n=3$ for both groups; $p<$ 0.001). 
Effect of $\mu$ OR gene knock-out on morphine-induced upregulation of cell surface $\delta O R$

In the dorsal horn of the spinal cord of untreated $\mu \mathrm{OR}$ KO mice, the cellular and subcellular distribution of immunoreactive $\delta \mathrm{OR}$ was similar to that observed in untreated WT mice (Figs. $8 A, 9 A$ ). In fact, no significant difference was observed in the overall density of immunogold particles (per dendritic unit area) in WT as compared with $\mu \mathrm{OR}$ KO mice (ANOVA, Bonferroni's MCT; $p>0.05$; Fig. 10A). In addition, both the proportion of immunogold particles associated with the plasma membrane and the density of $\delta$ OR per unit length of plasma membrane were identical to those observed in WT mice (Fig. $10 \mathrm{~B}$ ). The lack of difference in subcellular distribution between WT and $\mu \mathrm{OR}$ KO mice suggests that, under basal conditions, the presence of $\mu \mathrm{OR}$ is not required for the trafficking of $\delta \mathrm{OR}$ to the plasma membrane.

Morphine pretreatment of $\mu \mathrm{OR} \mathrm{KO}$ mice did not change the subcellular distribution of $\delta \mathrm{OR}$ within dendrites in the dorsal horn of the spinal cord (Fig. 9B). Indeed, neither the percentage of immunogold particles associated with the plasma membrane nor the density of gold particles detected per unit length of membrane was changed in morphinepretreated as compared with untreated $\mu$ OR KO mice (Fig. $10 B, C$; ANOVA, Bonferroni's MCT; $p>0.05$ ). Chronic pretreatment of $\mu \mathrm{OR} \mathrm{KO}$ mice with morphine also failed to produce any change in the density of immunogold particles per unit area of dendrites when compared with either untreated $\mu \mathrm{OR}$ $\mathrm{KO}$ mice or with morphine-pretreated WT mice (Fig. 10 A; ANOVA, $p>0.05$ ). These results conclusively demonstrate that morphine targets $\delta \mathrm{OR}$ to the plasma membrane via selective stimulation of $\mu \mathrm{OR}$.

\section{Discussion}

\section{Studies with rats}

We previously demonstrated that chronic treatment of rats with morphine leads to an increase in $\delta \mathrm{OR}$-mediated antinociception (Cahill et al., 2001b). A first objective of the present study was to determine whether this effect was a property unique to morphine or characteristic of other $\mu \mathrm{OR}$ agonists. Pretreatment with methadone, etorphine, and fentanyl resulted in increases in $\delta \mathrm{OR}$ mediated antinociception, as was observed with morphine. Because these drugs elicit acute antinociceptive effects in the tailflick test over a wide range of $\mathrm{ED}_{50}$ values, the potency of the $\mu \mathrm{OR}$ agonist used as a "primer" drug does not appear to be critical in mediating the enhanced $\delta \mathrm{OR}$ response. Similarly, the capacity of these drugs to induce $\mu \mathrm{OR}$ internalization is not a determining factor. Indeed, morphine was as effective as the other $\mu \mathrm{OR}$ agonists in inducing increased $\delta \mathrm{OR}$-mediated antinociception although it does not cause $\mu \mathrm{OR}$ internalization, in contrast to methadone, etorphine, and fentanyl (Keith et al., 1996, 1998;
Whistler et al., 1999; Trafton et al., 2000; He et al., 2002). However, the in vivo pharmacokinetic profile of the $\mu \mathrm{OR}$ agonist is important for producing the increase in $\delta \mathrm{OR}$-mediated antinociception. Indeed, an intermittent dosing regimen with fentanyl, in contrast to morphine, methadone, and etorphine, did not enhance $\delta \mathrm{OR}$ responsiveness. Fentanyl is characterized by a more rapid onset and duration of action than the other $\mu \mathrm{OR}$ agonists that were used, suggesting that continuous stimulation of $\mu \mathrm{OR}$ is necessary for induction of enhanced $\delta \mathrm{OR}$ responsiveness. Indeed, continuous delivery of fentanyl increased the effect of DLT when compared with saline-pretreated animals.

Continuous stimulation of $\mu \mathrm{OR}$ for up to $48 \mathrm{hr}$ was necessary to induce changes in $\delta \mathrm{OR}$ responsiveness, because no increase in DLT potency was observed after 24 or $36 \mathrm{hr}$ of treatment with morphine. One could argue that this enhanced responsiveness occurs only with the administration of a threshold cumulative dose of morphine. The results obtained with intermittent versus continuous delivery of fentanyl, however, do not support this interpretation. Indeed, the total amount of fentanyl delivered through the pumps over the $48 \mathrm{hr}$ period was considerably lower than the cumulative amount administered during the intermittent dosage regimen (4.8 vs $17 \mu \mathrm{g}$, respectively, for a $225 \mathrm{gm}$ rat). 
Untreated $\mu O R$ KO mice
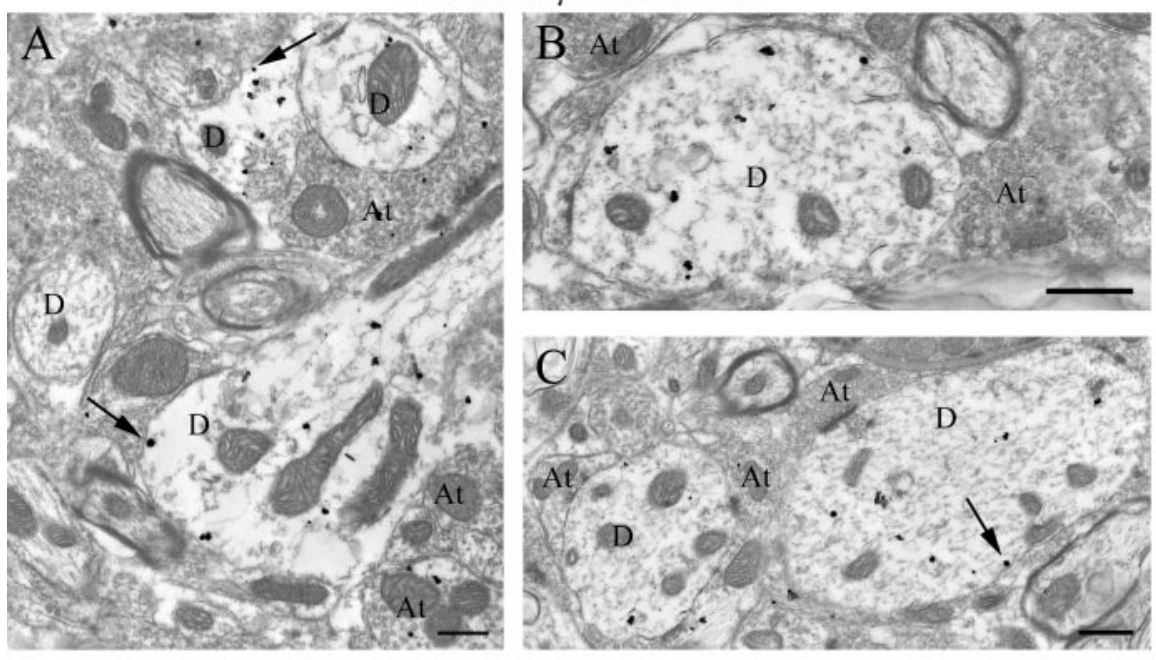

Morphine-pretreated $\mu$ OR KO mice
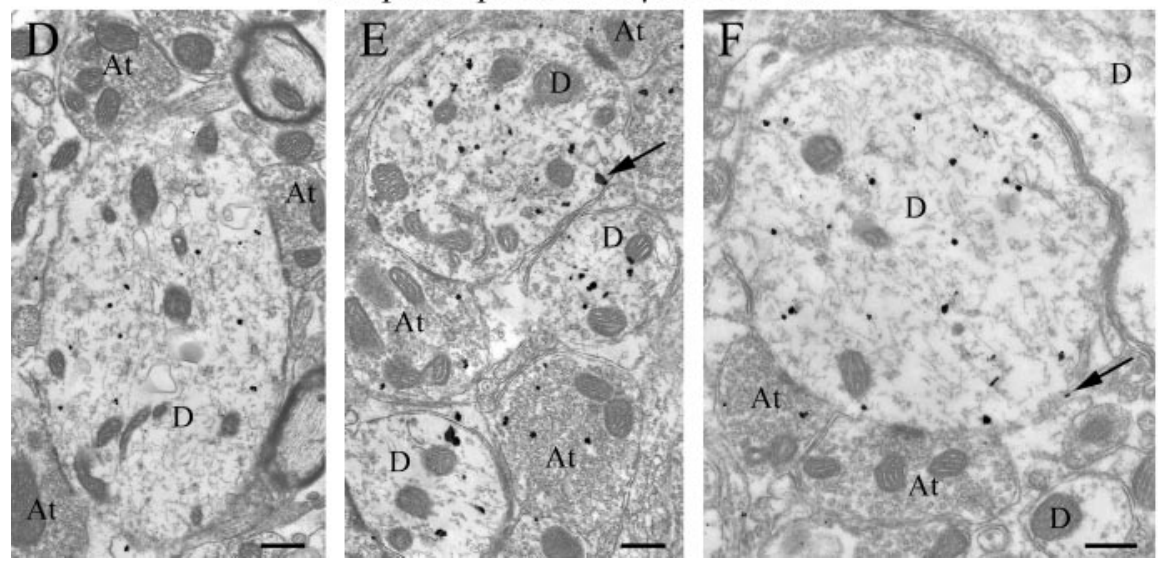

Figure 9. Immunogold electron microscopic localization of $\delta 0 R$ in the dorsal horn of the spinal cord of untreated and morphine-pretreated $\mu O R$ knock-out mice. $C 57 \mathrm{BL} / 6 \mathrm{KO}$ mice were pretreated $(D-F)$ or not $(A-C)$ with morphine as described and were processed for immunogold detection of $\delta 0 \mathrm{Rs} 12 \mathrm{hr}$ subsequent to the last morphine injection. In both untreated $(A-C)$ and morphine-pretreated ( $D-F) \mu O \mathrm{R} \mathrm{KO}$ mice the majority of immunogold particles is found within dendrites (labeled $D$ in $A-F$ ). Pretreatment with morphine does not change the proportion of $\delta 0 \mathrm{Rs}$ associated with the plasma membrane. Arrows denote gold particles in association with the plasma membrane. At, Axon terminal. Scale bars: $A-F, 0.5 \mu \mathrm{m}$.

Thus prolonged and sustained stimulation, rather than cumulative dosage, represents the important parameter in producing the enhancement of $\delta \mathrm{OR}$ agonist potency.

In a previous study we showed a correlation between the morphine-induced increase in $\delta \mathrm{OR}$-mediated antinociception and enhanced recruitment of intracellular $\delta$ ORs to neuronal plasma membranes in the dorsal horn of the rat spinal cord ( $\mathrm{Ca}$ hill et al., 2001b). The present results imply that this cell surface targeting requires at least $48 \mathrm{hr}$ of morphine pretreatment to occur. Such timing is considerably longer than previously documented for other receptor-mediated recruitment events. For example, treatment of hippocampal slices with insulin produced increased postsynaptic and dendritic plasma membrane density of $\mathrm{GABA}_{\mathrm{A}}$ receptors in the CA1 region in $<10 \mathrm{~min}$ (Wan et al., 1997). Moreover, dopamine $D_{1}$ receptor density was increased after a $1 \mathrm{~min}$ pretreatment with atrial natriuretic peptide (ANP) in both LLCPK and kidney cells, whereas neuropeptide Y-induced recruitment of the $\alpha_{1 \mathrm{~A}}$-adrenergic receptor to the plasma membrane in LLPCK cells was observed after only $10 \mathrm{sec}$ of stimulation (Holtbäck et al., 1999). The mechanisms govern- ing the morphine-induced recruitment of $\delta \mathrm{OR}$ therefore must differ from those implicated in the recruitment of these other receptor types and likely involve novel protein synthesis. A number of accessory proteins have been linked to cell surface recruitment of G-protein-coupled receptors (GPCRs; for review, see Bouvier, 2001; Brady and Limbird, 2002). For example, chaperone molecules, such as ninaA for the rhodopsin 1 receptor (Colley et al., 1991), calnexin for the vasopressin $V_{2}$ receptor (Morello et al., 2001), or RAMP-1 (receptor activity modifying protein 1 ) for the calcitonin receptor-like receptor (CRLR; McLatchie et al., 1998), can assist in the proper folding of proteins and/or trafficking of GPCRs to the plasma membrane. Similarly, the trafficking to the plasma membrane of type I metabotropic glutamate receptors (mGluR) appears to be regulated by the interplay of constitutively expressed and inducible members of the Homer family (Xiao et al., 1998; Roche et al., 1999; Ango et al., 2000, 2002; Sato et al., 2001). In the case of $\delta \mathrm{OR}$ it was proposed recently that intracellular chaperoning of the receptor from the endoplasmic reticulum to the cell surface by $\delta \mathrm{OR}$ agonists and antagonists may rescue improperly folded receptor proteins, leading to increased agonist binding (Petaja-Repo et al., 2002). Hence prolonged stimulation with a $\mu \mathrm{OR}$ agonist could induce the expression of a gene product involved in the trafficking/folding of $\delta$ ORs to the plasma membrane.

A number of studies have provided evidence for the involvement of $\delta \mathrm{OR}$ in the development and/or maintenance of morphine-induced tolerance (Abdelhamid et al., 1991; Fundytus et al., 1995; Kest et al., 1996; Hepburn et al., 1997; Zhao et al., 2002). Moreover, tolerance to repeated administration of morphine does not develop in $\delta$ OR KO mice (Zhu et al., 1999). Therefore, it was tempting to speculate that the $\mu \mathrm{OR}$-induced increase in $\delta \mathrm{OR}$ membrane density documented here might be implicated in producing the tolerance to $\mu \mathrm{OR}$ agonists observed after repeated stimulation with these agonists. However, the results of our acute morphine challenge experiments demonstrated that the enhanced recruitment of $\delta \mathrm{ORs}$ to the plasma membrane observed after chronic morphine pretreatment was not correlated directly with tolerance to morphine.

The morphine-induced enhancement of $\delta \mathrm{OR}$-mediated antinociception was no longer measurable $24 \mathrm{hr}$ after the last dose of the pretreatment, indicating that this effect is reversible. This reversibility is likely attributable to restoration of membranetargeted $\delta$ ORs to intracellular stores after cessation of morphine administration, because the decrease in $\delta \mathrm{OR}$-mediated antinociception was correlated with a return of immunoreactive $\delta \mathrm{OR}$ plasma membrane levels to basal values, as determined by electron microscopic immunocytochemistry. Because of the prolonged time course, constitutive internalization of $\delta \mathrm{OR}$ is the 
most likely explanation to account for this restoration of cell surface receptors to baseline; indeed, agonist-independent internalization recently has been shown for $\delta \mathrm{OR}$ in $\mathrm{CHO}$ cells transfected with this receptor (Trapaidze et al., 2000). Nonetheless, we cannot exclude the possibility that the cell surface density of $\delta \mathrm{OR}$ also decreases in response to steady-state endogenous release of opioid peptides. Indeed, $\delta$ ORs have been documented in neuro2A and HEK293 cells to be endocytosed efficiently after exposure to peptide agonists and to be targeted to lysosomes for degradation (Ko et al., 1999; Tsao and von Zastrow, 2000; Whistler et al., 2002), which would account for their lack of reappearance at the cell surface.

\section{Studies with mice}

To determine whether stimulation of $\mu \mathrm{OR}$ was necessary for targeting of $\delta \mathrm{ORs}$ to neuronal plasma membranes, we investigated the functionality and cellular distribution of $\delta \mathrm{OR}$ in mice with or lacking $\mu$ ORs.

Wild-type mice pretreated with morphine displayed the same enhancement of $\delta \mathrm{OR}$-mediated antinociception in a persistent pain paradigm as previously documented in rats (Cahill et al., $2001 \mathrm{~b})$. Also as observed in the rat, this change in $\delta \mathrm{OR}$ responsiveness was correlated with alterations in the subcellular distribution of $\delta$ ORs, as assessed by electron microscopic immunocytochemistry. Whereas in untreated animals the bulk of $\delta \mathrm{OR}$ immunoreactivity detected within layers II-V of the dorsal horn of the spinal cord was predominantly intracellular, as previously described in the rat (Cheng et al., 1995, 1997; Cahill et al., 2001a,b), in mice pretreated with morphine a significantly higher proportion of $\delta \mathrm{OR}$ was found in association with neuronal plasma membranes. This change in the subcellular distribution of $\delta$ ORs was not accompanied by an augmentation in total $\delta \mathrm{OR}$ protein levels, as assessed by electronic microscopic localization of $\delta$ ORs. These observations support the hypothesis that the increase in DLT-mediated antinociception is a consequence of mobilization of $\delta \mathrm{OR}$ from intracellular stores to the plasma membrane rather than of augmented receptor neosynthesis.

The overall density of $\delta$ ORs in layers II-V of the dorsal horn of the spinal cord was the same in WT and $\mu \mathrm{OR} \mathrm{KO}$ mice. These results are consistent with those of earlier radioligand binding studies with DPDPE and deltorphin-I, which also detected no major compensatory changes in total $\delta \mathrm{OR}$ expression in the brain of $\mu$ OR KO mice (Matthes et al., 1996; Kitchen et al., 1997; Sora et al., 1997; Loh et al., 1998; Chen et al., 2000) (for review, see Kieffer and Gavériaux-Ruff, 2002). The subcellular distribution (cell surface vs intracellular) of $\delta \mathrm{OR}$ was also similar between WT and $\mu \mathrm{OR} \mathrm{KO}$ mice, suggesting that the presence of $\mu \mathrm{OR}$ is not a prerequisite for the maintenance of $\delta \mathrm{OR}$ cell surface density at steady state and thus of the integrity of basal $\delta \mathrm{OR}$ responsiveness. Congruent with this interpretation, previous studies have reported similar levels of $\left[{ }^{35} \mathrm{~S}\right] \mathrm{GTP} \gamma \mathrm{S}$ binding in the brain of WT and $\mu \mathrm{OR} \mathrm{KO}$ mice in response to stimulation with deltorphin-I (Matthes et al., 1998; Hosohata et al., 2000). Furthermore, the antinociceptive potency of intrathecally administered deltorphin-I was identical between $\mu \mathrm{OR} \mathrm{KO}$ and WT mice (Hosohata et al., 2000), in accord with the present subcellular distribution results.
B

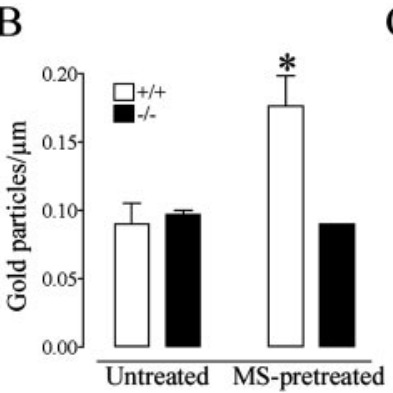

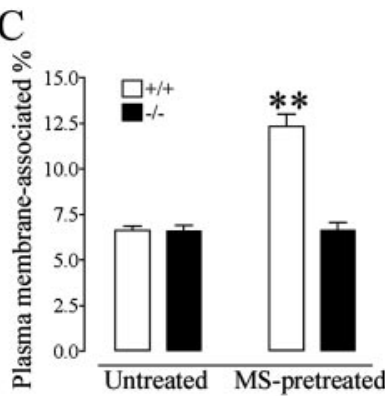

Figure 10. The presence of $\mu 0 \mathrm{R}$ is necessary for morphine-induced targeting of $\delta 0 \mathrm{R}$ to plasma membranes. $A$, Each bar represents the density of immunogold particles (particles/ $\mu \mathrm{m}^{2} ; n=3$ for each group). No statistically significant differences were observed (ANOVA; $p>0.05$ ). $B$, Each bar in the graph represents the density of immunogold particles per unit length of membrane. Morphine pretreatment markedly increases the density (from 0.09 to 0.18 ) in WT mice as compared with mice pretreated with morphine when compared with untreated WT mice (ANOVA, Bonferroni's MCT; ${ }^{* *} p<0.001$ ). No change in KO mice (ANOVA; $p>0.05$ ). In all panels $+/+$ denotes the WT, whereas $-/-$ represents $\mu 0 \mathrm{R} \mathrm{KO} \mathrm{C57BL/6} \mathrm{mice.} \mathrm{Data} \mathrm{are}$

Treatment of $\mu \mathrm{OR}$ KO mice with morphine did not promote recruitment of $\delta \mathrm{OR}$ to the plasma membrane from intracellular stores. This result provides important confirmation that the morphine-induced upregulation of cell surface $\delta \mathrm{OR}$ was, in fact, the result of morphine acting via selective stimulation of $\mu \mathrm{OR}$ and not via interaction with $\delta$ ORs or other targets. Nonetheless, it remains possible that events independent from $\mu \mathrm{OR}$ stimulation may be implicated in the upregulation of cell surface $\delta \mathrm{OR}$ and/or enhanced $\delta \mathrm{OR}$ responsiveness in $\mu \mathrm{OR}$ KO mice. Indeed, $\delta \mathrm{OR}$ agonists were found to produce significantly greater antihyperalgesia in $\mu \mathrm{OR} \mathrm{KO}$ mice when compared with WT mice injected with Complete Freund's Adjuvant (Qiu et al., 2000). Nonetheless, the present results demonstrate that $\mathrm{KO}$ animals may exhibit discrete phenotypic traits that can be evidenced only after pathophysiological or pharmacological challenge.

In conclusion, we have demonstrated that sustained pretreatment with different $\mu \mathrm{OR}$ agonists leads to a reversible increase in $\delta \mathrm{OR}-$ mediated antinociception in rats and mice and have established, via studies in $\mu$ OR KO mice, that this effect is entirely dependent on activation of $\mu \mathrm{OR}$. These results have important clinical ramifications because they suggest that "priming" of subjects with $\mu \mathrm{OR}$ agonists such as morphine could be exploited to increase the potency of $\delta \mathrm{OR}$ agonists.

\section{References}

Abdelhamid EE, Takemori AE (1991) Characteristics of $\mu$ and $\delta$ opioid binding sites in striatal slices of morphine-tolerant and -dependent mice. Eur J Pharmacol 198:157-163.

Abdelhamid EE, Sultana M, Portoghese PS, Takemori AE (1991) Selective blockage of $\delta$-opioid receptors prevents the development of morphine tolerance and dependence in mice. J Pharmacol Exp Ther 258:299-303.

Ango F, Pin JP, Tu JC, Xiao B, Worley PF, Bockaert J, Fagni L (2000) Dendritic and axonal targeting of type 5 metabotropic glutamate receptor is regulated by Homer1 proteins and neuronal excitation. J Neurosci 20:8710-8716.

Ango F, Robbe D, Tu JC, Xiao B, Worley PF, Pin JP, Bockaert J, Fagni L (2002) Homer-dependent cell surface expression of metabotropic glutamate receptor type 5 in neurons. Mol Cell Neurosci 20:323-329.

Arvidsson U, Dado RJ, Riedl M, Lee JH, Law PY, Loh HH, Elde R, Wessendorf MW (1995a) $\delta$-Opioid receptor immunoreactivity: distribution in brainstem and spinal cord, and relationship to biogenic amines and enkephalin. J Neurosci 15:1215-1235.

Arvidsson U, Riedl M, Chakrabarti S, Lee JH, Nakano AH, Dado RJ, Loh HH, 
Law PY, Wessendorf MW, Elde R (1995b) Distribution and targeting of a $\mu$-opioid receptor (MOR1) in brain and spinal cord. J Neurosci 15:3328-3341.

Besse D, Lombard MC, Zajac JM, Roques BP, Besson JM (1990) Pre- and postsynaptic location of mu, delta, and kappa opioid receptors in the superficial layers of the dorsal horn of the rat spinal cord. Prog Clin Biol Res 328:183-186.

Besse D, Lombard MC, Besson JM (1991) Autoradiographic distribution of $\mathrm{mu}$, delta, and kappa opioid binding sites in the superficial dorsal horn, over the rostrocaudal axis of the rat spinal cord. Brain Res 548:287-291.

Besse D, Lombard MC, Besson JM (1992a) Up-regulation of [ $\left.{ }^{3} \mathrm{H}\right]$ DAMGO and $\left[{ }^{3} \mathrm{H}\right]$ DTLET opioid binding sites in laminae I-II of the spinal cord in intact and deafferented morphine-tolerant rats. Neurosci Lett 136:209-212.

Besse D, Lombard MC, Besson JM (1992b) Plasticity of mu and delta opioid receptors in the superficial dorsal horn of the adult rat spinal cord following dorsal rhizotomies: a quantitative autoradiographic study. Eur J Neurosci 4:954-965.

Bouvier M (2001) Oligomerization of G-protein-coupled transmitter receptors. Nat Rev Neurosci 2:274-286.

Brady AE, Limbird LE (2002) G-protein-coupled receptor interacting proteins: emerging roles in localization and signal transduction. Cell Signal 14:297-309.

Cahill CM, McClellan KA, Morinville A, Hoffert C, Hubatsch D, O’Donnell D, Beaudet A (2001a) Immunohistochemical distribution of $\delta$-opioid receptors in the rat central nervous system: evidence for somatodendritic labeling and antigen-specific cellular compartmentalization. J Comp Neurol 440:65-84.

Cahill CM, Morinville A, Lee MC, Vincent JP, Collier B, Beaudet A (2001b) Prolonged morphine treatment targets $\delta$-opioid receptors to neuronal plasma membranes and enhances $\delta$-mediated antinociception. J Neurosci 21:7598-7607.

Chen H, Seybold VS, Loh HH (2000) An autoradiographic study in $\mu$-opioid receptor knockout mice. Brain Res Mol Brain Res 76:170-172.

Chen Y, Mestek A, Liu J, Hurley JA, Yu L (1993) Molecular cloning and functional expression of a $\mu$-opioid receptor from rat brain. Mol Pharmacol 44:8-12.

Cheng PY, Svingos AL, Wang H, Clarke CL, Jenab S, Beczkowska IW, Inturrisi CE, Pickel VM (1995) Ultrastructural immunolabeling shows prominent presynaptic vesicular localization of $\delta$-opioid receptor within both enkephalin- and nonenkephalin-containing axon terminals in the superficial layers of the rat cervical spinal cord. J Neurosci 15:5976-5988.

Cheng PY, Liu-Chen LY, Pickel VM (1997) Dual ultrastructural immunocytochemical labeling of mu and delta opioid receptors in the superficial layers of the rat cervical spinal cord. Brain Res 778:367-380.

Coderre TJ, Fundytus ME, McKenna JE, Dalal S, Melzack R (1993) The formalin test: a validation of the weighted-scores method of behavioural pain rating. Pain 54:43-50.

Coggeshall RE, Carlton SM (1997) Receptor localization in the mammalian dorsal horn and primary afferent neurons. Brain Res Brain Res Rev 24:28-66.

Colley NJ, Baker EK, Stamnes MA, Zuker CS (1991) The cyclophilin homolog ninaA is required in the secretory pathway. Cell 67:255-263.

Dado RJ, Law PY, Loh HH, Elde R (1993) Immunofluorescent identification of a delta-opioid receptor on primary afferent nerve terminals. NeuroReport 5:341-344.

Evans CJ, Keith Jr DE, Morrison H, Magendzo K, Edwards RH (1992) Cloning of a delta opioid receptor by functional expression. Science 258:1952-1955.

Fukuda K, Kato S, Mori K, Nishi M, Takeshima H (1993) Primary structures and expression from cDNAs of rat opioid receptor $\delta$ - and $\mu$-subtypes. FEBS Lett 327:311-314.

Fundytus ME, Schiller PW, Shapiro M, Weltrowska G, Coderre TJ (1995) Attenuation of morphine tolerance and dependence with the highly selective $\delta$-opioid receptor antagonist TIPP $[\psi]$. Eur J Pharmacol 286:105-108.

George SR, Fan T, Xie Z, Tse R, Tam V, Varghese G, O'Dowd BF (2000) Oligomerization of $\mu$ - and $\delta$-opioid receptors. Generation of novel functional properties. J Biol Chem 275:26128-26135.

Gomes I, Jordan BA, Gupta A, Trapaidze N, Nagy V, Devi LA (2000) Heterodimerization of mu and delta opioid receptors: a role in opiate synergy. J Neurosci 20:RC110(1-5).

Gouardères C, Jhamandas K, Cridland R, Cros J, Quirion R, Zajac JM (1993) Opioid and substance $\mathrm{P}$ receptor adaptations in the rat spinal cord fol- lowing sub-chronic intrathecal treatment with morphine and naloxone. Neuroscience 54:799-807.

Gutstein HB, Akil H (2001) Opioid analgesics. In: Goodman and Gilman's the pharmacological basis of therapeutics, 10th Ed (Hardman JG, Limbird LE, Goodman Gilman A, eds), pp 569-619. New York: McGraw-Hill.

He L, Fong J, von Zastrow M, Whistler JL (2002) Regulation of opioid receptor trafficking and morphine tolerance by receptor oligomerization. Cell 108:271-282.

Hepburn MJ, Little PJ, Gingras J, Kuhn CM (1997) Differential effects of naltrindole on morphine-induced tolerance and physical dependence in rats. J Pharmacol Exp Ther 281:1350-1356.

Heyman JS, Mulvaney SA, Mosberg HI, Porreca F (1987) Opioid $\delta$-receptor involvement in supraspinal and spinal antinociception in mice. Brain Res 420:100-108.

Heyman JS, Jiang Q, Rothman RB, Mosberg HI, Porreca F (1989a) Modulation of $\mu$-mediated antinociception by $\delta$ agonists: characterization with antagonists. Eur J Pharmacol 169:43-52.

Heyman JS, Vaught JL, Mosberg HI, Haaseth RC, Porreca F (1989b) Modulation of $\mu$-mediated antinociception by $\delta$ agonists in the mouse: selective potentiation of morphine and normorphine by [D-Pen2,DPen5] enkephalin. Eur J Pharmacol 165:1-10.

Holtbäck U, Brismar H, DiBona GF, Fu M, Greengard P, Aperia A (1999) Receptor recruitment: a mechanism for interactions between G-proteincoupled receptors. Proc Natl Acad Sci USA 96:7271-7275.

Hosohata Y, Vanderah TW, Burkey TH, Ossipov MH, Kovelowski CJ, Sora I, Uhl GR, Zhang X, Rice KC, Roeske WR, Hruby VJ, Yamamura HI, Lai J, Porreca F (2000) $\delta$-Opioid receptor agonists produce antinociception and $\left[{ }^{35} \mathrm{~S}\right] \mathrm{GTP} \gamma \mathrm{S}$ binding in $\mu$-receptor knock-out mice. Eur J Pharmacol 388:241-248.

Ji RR, Zhang Q, Law PY, Low HH, Elde R, Hokfelt T (1995) Expression of $\mu$-, $\delta$-, and $\kappa$-opioid receptor-like immunoreactivities in rat dorsal root ganglia after carrageenan-induced inflammation. J Neurosci 15:8156-8166.

Jiang Q, Mosberg HI, Porreca F (1990) Selective modulation of morphine antinociception, but not development of tolerance, by $\delta$ receptor agonists. Eur J Pharmacol 186:137-141.

Keith DE, Murray SR, Zaki PA, Chu PC, Lissin DV, Kang L, Evans CJ, von Zastrow M (1996) Morphine activates opioid receptors without causing their rapid internalization. J Biol Chem 271:19021-19024.

Keith DE, Anton B, Murray SR, Zaki PA, Chu PC, Lissin DV, MonteilletAgius G, Stewart PL, Evans CJ, von Zastrow M (1998) $\mu$-Opioid receptor internalization: opiate drugs have differential effects on a conserved endocytic mechanism in vitro and in the mammalian brain. Mol Pharmacol 53:377-384.

Kest B, Lee CE, McLemore GL, Inturrisi CE (1996) An antisense oligodeoxynucleotide to the delta opioid receptor (DOR-1) inhibits morphine tolerance and acute dependence in mice. Brain Res Bull 39:185-188.

Kieffer BL, Gaveriaux-Ruff C (2002) Exploring the opioid system by gene knockout. Prog Neurobiol 66:285-306.

Kieffer BL, Befort K, Gavériaux-Ruff C, Hirth CG (1992) The $\delta$-opioid receptor: isolation of a cDNA by expression cloning and pharmacological characterization. Proc Natl Acad Sci USA 89:12048-12052.

Kitchen I, Slowe SJ, Matthes HW, Kieffer B (1997) Quantitative autoradiographic mapping of mu-, delta- and kappa-opioid receptors in knockout mice lacking the mu-opioid receptor gene. Brain Res 778:73-88.

Ko JL, Arvidsson U, Williams FG, Law PY, Elde R, Loh HH (1999) Visualization of time-dependent redistribution of $\delta$-opioid receptors in neuronal cells during prolonged agonist exposure. Brain Res Mol Brain Res 69:171-185.

Loh HH, Liu HC, Cavalli A, Yang W, Chen YF, Wei LN (1998) $\mu$-Opioid receptor knockout in mice: effects on ligand-induced analgesia and morphine lethality. Brain Res Mol Brain Res 54:321-326.

Lord JA, Waterfield AA, Hughes J, Kosterlitz HW (1977) Endogenous opioid peptides: multiple agonists and receptors. Nature 267:495-499.

Malmberg AB, Yaksh TL (1992) Isobolographic and dose-response analyses of the interaction between intrathecal $\mathrm{mu}$ and delta agonists: effects of naltrindole and its benzofuran analog (NTB). J Pharmacol Exp Ther 263:264-275.

Mansour A, Fox CA, Akil H, Watson SJ (1995) Opioid-receptor mRNA expression in the rat CNS: anatomical and functional implications. Trends Neurosci 18:22-29.

Martin WR, Eades CG, Thompson JA, Huppler RE, Gilbert PE (1976) The effects of morphine- and nalorphine-like drugs in the nondependent and 
morphine-dependent chronic spinal dog. J Pharmacol Exp Ther 197:517-532.

Matthes HW, Maldonado R, Simonin F, Valverde O, Slowe S, Kitchen I, Befort K, Dierich A, Le Meur M, Dolle P, Tzavara E, Hanoune J, Roques BP, Kieffer BL (1996) Loss of morphine-induced analgesia, reward effect and withdrawal symptoms in mice lacking the $\mu$-opioid receptor gene. Nature 383:819-823.

Matthes HW, Smadja C, Valverde O, Vonesch JL, Foutz AS, Boudinot E, Denavit-Saubie M, Severini C, Negri L, Roques BP, Maldonado R, Kieffer BL (1998) Activity of the $\delta$-opioid receptor is partially reduced, whereas activity of the $\kappa$-receptor is maintained in mice lacking the $\mu$-receptor. J Neurosci 18:7285-7295.

Mattia A, Farmer SC, Takemori AE, Sultana M, Portoghese PS, Mosberg HI, Bowen WD, Porreca F (1992) Spinal opioid delta antinociception in the mouse: mediation by a $5^{\prime}$-NTII-sensitive delta receptor subtype. J Pharmacol Exp Ther 260:518-525.

McLatchie LM, Fraser NJ, Main MJ, Wise A, Brown J, Thompson N, Solari R, Lee MG, Foord SM (1998) RAMPs regulate the transport and ligand specificity of the calcitonin receptor-like receptor. Nature 393:333-339.

Meng F, Xie GX, Thompson RC, Mansour A, Goldstein A, Watson SJ, Akil H (1993) Cloning and pharmacological characterization of a rat kappa opioid receptor. Proc Natl Acad Sci USA 90:9954-9958.

Minami M, Maekawa K, Yabuuchi K, Satoh M (1995) Double in situ hybridization study on coexistence of $\mu$-, $\delta$ - and $\kappa$-opioid receptor mRNAs with preprotachykinin A mRNA in the rat dorsal root ganglia. Brain Res Mol Brain Res 30:203-210.

Mogil JS, Wilson SG, Bon K, Lee SE, Chung K, Raber P, Pieper JO, Hain HS, Belknap JK, Hubert L, Elmer GI, Chung JM, Devor M (1999) Heritability of nociception I: responses of 11 inbred mouse strains on 12 measures of nociception. Pain 80:67-82.

Morello JP, Salahpour A, Petaja-Repo UE, Laperriere A, Lonergan M, Arthus MF, Nabi IR, Bichet DG, Bouvier M (2001) Association of calnexin with wild type and mutant AVPR2 that causes nephrogenic diabetes insipidus. Biochemistry 40:6766-6775.

Petaja-Repo UE, Hogue M, Bhalla S, Laperriere A, Morello JP, Bouvier M (2002) Ligands act as pharmacological chaperones and increase the efficiency of delta opioid receptor maturation. EMBO J 21:1628-1637.

Porreca F, Jiang Q, Tallarida RJ (1990) Modulation of morphine antinociception by peripheral [Leu5] enkephalin: a synergistic interaction. Eur J Pharmacol 179:463-468.

Qiu C, Sora I, Ren K, Uhl G, Dubner R (2000) Enhanced $\delta$-opioid receptormediated antinociception in $\mu$-opioid receptor-deficient mice. Eur J Pharmacol 387:163-169.

Roche KW, Tu JC, Petralia RS, Xiao B, Wenthold RJ, Worley PF (1999) Homer $1 \mathrm{~b}$ regulates the trafficking of group I metabotropic glutamate receptors. J Biol Chem 274:25953-25957.

Rothman RB, Danks JA, Jacobson AE, Burke Jr TR, Rice KC, Tortella FC, Holaday JW (1986) Morphine tolerance increases $\mu$-noncompetitive $\delta$ binding sites. Eur J Pharmacol 124:113-119.

Sato M, Suzuki K, Nakanishi S (2001) NMDA receptor stimulation and brain-derived neurotrophic factor upregulate Homer 1a mRNA via the mitogen-activated protein kinase cascade in cultured cerebellar granule cells. J Neurosci 21:3797-3805.

Sora I, Takahashi N, Funada M, Ujike H, Revay RS, Donovan DM, Miner LL, Uhl GR (1997) Opiate receptor knockout mice define mu receptor roles in endogenous nociceptive responses and morphine-induced analgesia. Proc Natl Acad Sci USA 94:1544-1549.

Stewart PE, Hammond DL (1993) Evidence for delta opioid receptor subtypes in rat spinal cord: studies with intrathecal naltriben, cyclic[DPen2,D-Pen5] enkephalin and [ D-Ala2,Glu4]deltorphin. J Pharmacol Exp Ther 266:820-828.

Thompson RC, Mansour A, Akil H, Watson SJ (1993) Cloning and pharmacological characterization of a rat mu opioid receptor. Neuron 11:903-913.

Trafton JA, Abbadie C, Marek K, Basbaum AI (2000) Postsynaptic signaling via the $\mu$-opioid receptor: responses of dorsal horn neurons to exogenous opioids and noxious stimulation. J Neurosci 20:8578-8584.

Trapaidze N, Gomes I, Bansinath M, Devi LA (2000) Recycling and resensitization of delta opioid receptors. DNA Cell Biol 19:195-204.

Tsao PI, von Zastrow M (2000) Type-specific sorting of G-protein-coupled receptors after endocytosis. J Biol Chem 275:11130-11140.

Wan Q, Xiong ZG, Man HY, Ackerley CA, Braunton J, Lu WY, Becker LE, MacDonald JF, Wang YT (1997) Recruitment of functional GABA $\mathrm{A}_{\mathrm{A}}$ receptors to postsynaptic domains by insulin. Nature 388:686-690.

Wang H, Wessendorf MW (2001) Equal proportions of small and large DRG neurons express opioid receptor mRNAs. J Comp Neurol 429:590-600.

Wang JB, Imai Y, Eppler CM, Gregor P, Spivak CE, Uhl GR (1993) $\mu$-Opiate receptor: cDNA cloning and expression. Proc Natl Acad Sci USA 90:10230-10234.

Whistler JL, Chuang HH, Chu P, Jan LY, von Zastrow M (1999) Functional dissociation of mu opioid receptor signaling and endocytosis: implications for the biology of opiate tolerance and addiction. Neuron 23:737-746.

Whistler JL, Enquist J, Marley A, Fong J, Gladher F, Tsuruda P, Murray SR, von Zastrow M (2002) Modulation of postendocytic sorting of G-protein-coupled receptors. Science 297:615-620.

Xiao B, Tu JC, Petralia RS, Yuan JP, Doan A, Breder CD, Ruggiero A, Lanahan AA, Wenthold RJ, Worley PF (1998) Homer regulates the association of group 1 metabotropic glutamate receptors with multivalent complexes of Homer-related, synaptic proteins. Neuron 21:707-716.

Yaksh TL, Rudy TA (1976) Analgesia mediated by a direct spinal action of narcotics. Science 192:1357-1358.

Yaksh TL, Rudy TA (1977) Studies on the direct spinal action of narcotics in the production of analgesia in the rat. J Pharmacol Exp Ther 202:411-428.

Yasuda K, Raynor K, Kong H, Breder CD, Takeda J, Reisine T, Bell GI (1993) Cloning and functional comparison of kappa and delta opioid receptors from mouse brain. Proc Natl Acad Sci USA 90:6736-6740.

Zerari F, Zouaoui D, Gastard M, Apartis E, Fischer J, Herbrecht F, Cupo A, Cucumel K, Conrath M (1994) Ultrastructural study of $\delta$-opioid receptors in the dorsal horn of the rat spinal cord using monoclonal antiidiotypic antibodies. J Chem Neuroanat 7:159-170.

Zhao GM, Wu D, Soong Y, Shimoyama M, Berezowska I, Schiller PW, Szeto HH (2002) Profound spinal tolerance after repeated exposure to a highly selective mu-opioid peptide agonist: role of $\delta$-opioid receptors. J Pharmacol Exp Ther 302:188-196.

Zhu Y, King MA, Schuller AG, Nitsche JF, Reidl M, Elde RP, Unterwald E, Pasternak GW, Pintar JE (1999) Retention of supraspinal $\delta$-like analgesia and loss of morphine tolerance in $\delta$ opioid receptor knockout mice. Neuron 24:243-252. 